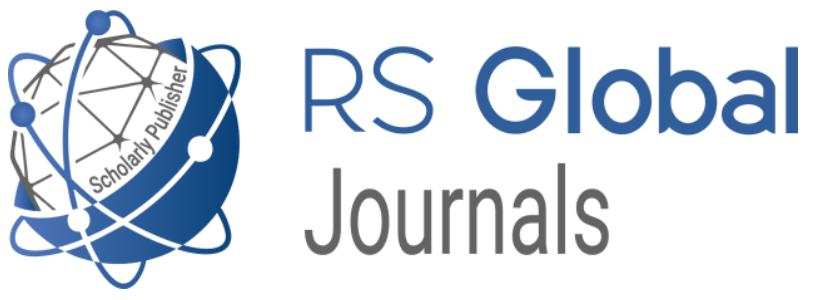

Scholarly Publisher

RS Global Sp. z O.O.

ISNI: 0000000484952390

Dolna 17, Warsaw, Poland 00-773

Tel: +48226022703

Email: editorial_office@rsglobal.pl

JOURNAL International Journal of Innovative Technologies in Social Science

p-ISSN $2544-9338$

e-ISSN

2544-9435

PUBLISHER

RS Global Sp. z O.O., Poland

ARTICLE TITLE

ФОРМУВАННЯ КОМУНІКАТИВНОЇ КУЛЬТУРИ ДИРИГЕНТА ОРКЕСТРОВОГО КОЛЕКТИВУ У ПРОЦЕСІ ТВОРЧОЇ ДІЯЛЬНОСТІ

$\operatorname{AUTHOR}(\mathbf{S})$

Пастушок Тарас Васильович

Pastushok T. V. (2021) Formation of the Communicative Culture of the Conductor of the Orchestra in the Process of Creative

ARTICLE INFO Activity. International Journal of Innovative Technologies in Social Science. 2(30).

doi: 10.31435/rsglobal_ijitss/30062021/7554

DOI

https://doi.org/10.31435/rsglobal_ijitss/30062021/7554

RECEIVED

15 April 2021

ACCEPTED

24 May 2021

PUBLISHED

28 May 2021

LICENSE

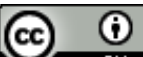

This work is licensed under a Creative Commons Attribution

4.0 International License.

(C) The author(s) 2021. This publication is an open access article. 


\title{
ФОРМУВАННЯ КОМУНІКАТИВНОЇ КУЛЬТУРИ ДИРИГЕНТА ОРКЕСТРОВОГО КОЛЕКТИВУ У ПРОЦЕСІ ТВОРЧОЇ ДІЯЛЬНОСТІ
}

\author{
Пастушок Тарас Васильович, аспірант Рівненського державного гуманітарного \\ університету, м. Рівне, Україна, ORCID ID: https://orcid.org/0000-0002-7119-3554
}

DOI: https://doi.org/10.31435/rsglobal_ijitss/30062021/7554

\section{ARTICLE INFO \\ Received 15 April 2021 \\ Accepted 24 May 2021 \\ Published 28 May 2021}

\section{KEYWORDS}

conductor, orchestra, communicative culture, pedagogical conditions, orchestral score.

\begin{abstract}
This article analyzes the role of communicative culture in fostering creative relationships between the conductor and members of the orchestra. Besides, the structural stages of mutual communicative communication were identified. In this research the author proclaimed that the communication and creative interaction between the conductor of the orchestra and its members takes place in the form of creative dialogue, because the conductor communicates with the orchestra through a conductor's gesture and facial expressions. However, the previous interpretation of artistic material (comments, instructions, requests, explanations of technical material and means of expression (dynamics, strokes, accuracy of rhythmic elements of the work, etc.)) is due to the communicative interaction of speech communication.

The main means of communication between the conductor and the orchestra is the creative process. In this regard, at the final stage of dialogue between the conductor and the members of the orchestra, the communicative abilities of the conductor play a special role in achieving the highest quality result of creative interaction and cooperation.
\end{abstract}

Citation: Pastushok T. V. (2021) Formation of the Communicative Culture of the Conductor of the Orchestra in the Process of Creative Activity. International Journal of Innovative Technologies in Social Science. 2(30). doi: 10.31435/rsglobal_ijitss/30062021/7554

Copyright: (C) 2021 Pastushok T. V. This is an open-access article distributed under the terms of the Creative Commons Attribution License (CC BY). The use, distribution or reproduction in other forums is permitted, provided the original author(s) or licensor are credited and that the original publication in this journal is cited, in accordance with accepted academic practice. No use, distribution or reproduction is permitted which does not comply with these terms.

Постановка проблеми. Диригування є складним процесом, який передбачає керування музичним колективом під час виконання художнього твору. Диригування, один із складних видів музичного мистецтва, включаючий в себе ряд наук, зокрема музичну педагогіку та елементи психології. Я. Сверлюк (2002) 3 цього приводу зауважує, що мистецтво комунікативного впливу диригента на учасників оркестрового колективу не повністю досліджене, тому методичних рекомендацій на даний час існує не багато (с. 63). Розв'язання даної проблеми дасть змогу більш детально розглянути проблему комунікативної взаємодії диригента та учасників оркестрового колективу.

Диригування, як один із видів мистецтва сьогодні розглядається спільною взаємодією керівника та учасників оркестрового колективу і $\epsilon$ «мистецтвом управління колективним виконавством». Особливо актуальним $\epsilon$ процес удосконалення комунікативних якостей диригента оркестру. Специфікою професії диригента оркестрового колективу $\epsilon$ саме організація та спрямування відповідної кількості учасників оркестрового колективу, яка в свою чергу вимагає поглибленого вивчення даної проблеми та професійного підходу до неї.

Мета статті - розглянути комунікативну культуру диригента, як основний елемент впливу та взаємодії з учасниками оркестрового колективу.

Аналіз наукових досліджень. Проблема формування комунікативної культури керівника оркестрового колективу в тих чи інших аспектах була досліджена у наукових працях 
Л. Стоковського, Г. Сржемського, Л. Живова, І. Мусіна, Я. Сверлюка, Г. Макаренка. Оновою для роз'яснення теоретичних засад формування комунікативних вмінь та навичок диригента оркестрового колективу становить положення про комунікацію та культуру (М. Попович, Л. Стоковський, І. Маркевич, Й. Зізіулас, Є. Вєрєщагін ).

Виклад основного матеріалу. На сьогоднішній день, про диригування, як один з видів мистецтва написано чимало наукових праць. Аналізуючи їх, можна стверджувати, що сам процес керування оркестровим колективом досліджений в різних жанрах та стилях музичного спрямування. Проте індивідуальний підхід диригента до оркестру, а саме розвиток його комунікативної культури не має вагомих наукових досліджень.

Як відзначає М. Малько (1965), - «техніка диригування» - це мова жестів, завдяки яким звертається диригент до хору, чи оркестру (с. 86). Відповідно, диригент повинен володіти цією мовою, і вірно ії доносити до оркестрантів. Л. Стоковський (1959) називає «диригування» як одну із непередбачуваних галузей музичного мистецтва (с. 387). Він зауважує, що в зміст диригентського мистецтва також входить наявність навичок управління учасниками оркестрового колективу. І. Маркевич (1970) продовжуючи цю думку, заявляє, що «диригування, як наука», включає в себе три основні елементи: мистецтво, наука та управління (с. 263).

У теперішній час поняття «культура» має близько сотні визначень, про те основне тлумачення об'єднує в собі усі елементи. Культура (лат. Culture - «обробіток», «обробляти») - сукупність матеріальних та духовних цінностей, створених людством протягом його історії; історично набутий набір правил всередині соціуму для його збереження та гармонізації (Бусел, 2005 , с. 810). Термін культура розділяє між собою такі основні напрямки:

- наука і освіта (включаючи і всі технологічні напрямки),

- мистецтво (живопис, література, музика та інші галузі),

- мораль людини та ії світогляд.

У навчальних закладах культура, як правило вивчається комплексом різних гуманітарних наук, а саме культурологією, соціологією, етнографією, історією, культурною антропологією, психологією, тощо (Попович, 2006. с.60-61).

Термін «комунікація» в даному дослідженні відіграє особливу роль, так як це і є спосіб передачі знань. Комунікація (від лат. communicatio - єдність, передача, з'єднання, повідомлення, пов'язаного з дієсловом лат. сотmunico - роблю спільним, повідомляю, з'єдную, похідним від лат. communis - спільний) — це процес обміну інформацією (ідеями, поглядами, емоціями тощо) між двома або більше особами, спілкування за допомогою вербальних і невербальних засобів із метою передавання та одержання інформації (Бусел, 2005, с. 784).

Одною із перших згадок про комунікацію було використано у філософа К. Ясперса та німецьких філософів К. Апель та Ю. Габермас (2005). Вона поділялася на зовнішню (характеризувалася волею до пізнання, творчості, влади, любові, толерантності та свободи) та внутрішню (спрямована на смисложиттєві орієнтації та зумовлена волею до самозбереження), (с. 73).

Пізніше, 3 розвитком технічних засобів передачі інформації, поняття «комунікація» об’єднало в собі ряд самостійних наук. 3 початком ери «радіо» $(1920$ - ті роки), а пізніше появою телебачення та комп'ютерів, починається розвиток різних теорій комунікації, які в свою чергу характеризується становленням інформатики, семіотики, кібернетики та іншими складними математичними науками (Бориснєв, 2003, с. 7-8).

Поняття «комунікативна культура» має декілька різних тлумачень. Якщо дослівно, то це спосіб порозуміння між людьми. Свого роду, також комунікативною культурою можна назвати і правильне вживання мови, і певне підстроювання під ситуацію при спілкуванні, а ще - це максимально правильна поведінка, яка використовується у різних видах діалогів (Верещагин, 1990, с. 250).

Протягом всієї історії еволюції людського спілкування можна зазначити, що спосіб передачі певного досвіду та знань відбувався за рахунок взаємодії вчителя та учня. Для прикладу, можна сказати, що в Новому завіті комунікативна культура представлена Христом та його учнями, де він наводить приклад різних життєвих ситуацій, розказуючи притчі (Джузеппе, Р., 1979, с. 180-186).

У формуванні комунікативної культури майбутнього диригента в процесі роботи 3 оркестром $є$ ряд важливих чинників, які впливають на перспективу розвитку функціонування колективу. В зв'язку з цим проблема створення теоретичних та методичних основ підготовки 
майбутнього диригента $є$ досить актуальною в сучасному мистецтвознавчому світі. Для прикладу, Л. Стоковський вважає диригування одним із недосконалих видів музичного мистецтва.

В умовах сьогодення, до комунікативних умінь, якими має володіти диригент сучасного оркестрового колективу належать:

- адекватна оцінка кожного учасника оркестрового колективу, його психологічний стан та професійні якості,

- володіти «читанням 3 обличчя» емоційним станом всіх учасників оркестру. В свою чергу В. Живов (1998) зазначає, що велике значення в розвитку комунікативної культури майбутнього диригента має мовленнєве спілкування за допомогою художніх образів (с. 130).

Відповідно, можна зазначити, що мистецтво спілкування диригента 3 учасниками оркестрового колективу має належну теоретичну основу. Негативним чинником у висвітленні даної проблеми являється саме відсутність чітких орієнтирів осмислення комунікативної взаємодії диригента та учасників оркестрового колективу, які в свою чергу пов'язані із розкриттям характерних проблем керування музичним колективом, з урахуванням вікових та психологічних особливостей оркестрантів. Відповідно, дане спілкування в репетиційній роботі $\epsilon$ складним процесом взаємодії диригента та встановлення контакту із учасниками оркестрового колективу, як об'єктом власної професійної діяльності для подальшого виконання художніх завдань. Тому взаємодію та комунікативну культуру майбутнього диригента можна вважати основним елементом професійного спілкування із артистами оркестрового колективу.

Комунікативна культура майбутнього диригента складається 3 трьох елементів, які в поєднанні сприяють професійній взаємодії та творчого розвитку оркестрового колективу в цілому. Один із основних елементів $є$ педагогічний аспект - елемент культури диригента, який передбачає передачу вмінь та навичок учасникам оркестрового колективу. Виконавський аспект - визначає професійний рівень підготовки керівника оркестрового колективу. Управлінський аспект - визначає рівень когнітивної підготовки, організаторських здібностей та набутого авторитету майбутнього диригента.

Процес взаємодії керівника оркестру та його учасників несе у собі взаємообмін інформації, встановлення та розвитку контакту з кожним оркестрантом, а також зацікавленість у досягненні максимального результату в спільній креативній роботі. Особливістю даного процесу є досягнення взаєморозуміння, яке характерне тільки в випадку набуття майбутнім диригентом комунікативної культури та навичок спілкування з учасниками оркестрового колективу.

В своій науковій праці Г. Єржемський (1988) вважає, що ключовим елементом успішної роботи диригента та оркестрантів є їхня спільна взаємоувага (с.80). На його думку, відсутність уваги учасників оркестрового колективу, а особливо керівника призводить до неякісного опрацювання матеріалу, загальної байдужості результативності та руйнує всю загальну систему ï взаємодій. Тому диригент повинен дисциплінувати оркестрантів, підтримувати психологічний контакт з учасниками оркестрового колективу та знати систему побудови комунікативного спілкування. Доповнюючи цю думку, американський психолог Д. Карнегі (1991) вважає, що, вміння спілкуватися становить понад $80 \%$ успіху, тоді, як лиш $20 \%$ характеризується професійними знаннями людини (с.202). Тому можна зробити висновок, що комунікативна культура майбутнього диригента оркестрового колективу повинна базуватися на сформованих знаннях спілкування з оркестрантами.

Особливістю комунікативної культури диригента та учасників оркестрового колективу є різновид кількох груп відносин. Окрім професійних, тут зустрічаються громадські та особистісні. Які б не були взаємовідносини між керівником та оркестрантами, вони не можуть бути спрямовані лише в професійному складнику. Результат виконання вказівок диригента передбачає комунікативну взаємодію у всіх сферах відносин, зокрема міжособистісних, ділових та навіть конфліктних ситуаціях для досягнення певної мети.

На даний момент, комунікативна взаємодія диригента та оркестрантів за допомогою всіх видів відносин позитивно впливає на розвиток оркестрового виконавства. Тому в перспективі, такі комунікативні відносини між диригентом та учасниками оркестрового колективу сприяє ефективному результату загальної творчої роботи.

Основним завданням диригента безпосередньо залишається організація спільної творчої роботи оркестрового колективу, яка в подальшому буде спрямована на музичне виховання. Дана діяльність включає в себе організаційний аспект, спільне музикування та визначення мети цієї 
діяльності. На думку І. Мусіна (1967), «мова диригента повинна бути чітка, лаконічна, коротка, стисла, образна та обов'язково яскрава» (с. 352). Тому в репетиційному процесі диригент постійно застосовує комунікативну взаємодію через словесне пояснення, як найдоступнішу форму пояснення музично-слухових уявлень про партитуру та диригентський жест.

Про те, діалог між диригентом та оркестровим колективом також може здійснюватися завдяки певним видам комунікації: розповідь, пояснення, зауваження, ілюстрації, вимога, прохання, бесіда.

Завдяки розповіді відбувається спілкування диригента з оркестровим колективом, для якого притаманний опис подій чи характеристика елементів музичного матеріалу. Такий вид діалогу як пояснення сприяє розумінню більш точного опису термінів, явищ та історичних подій, які пробуджують в оркестрантів інтерес до музичного матеріалу. Зауваження спрямоване на лаконічне виправлення диригентом помилок, що мають місце в колективному виконавстві. Така форма діалогічного спілкування досить часто використовується у репетиційному процесі. Ілюстрація - показ диригентом наочних засобів для навчання, а саме: особисте диригування, показ партитур, слухання музичного матеріалу та фонограм, спів партій 3 оркестрової партитури, тощо. За допомогою цих засобів ілюстрації, диригент, як правило часто застосовує негативні та позитивні зразки виконавства, які дають оркестрантам змогу чітко осмислити майбутню мету творчої роботи всього оркестрового колективу. Вимога - спеціальний вид діалогу диригента 3 оркестрантами, який передбачає точного вербального виконання тих чи інших дій диригента. Якщо дана вимога відбувається не точно, то відбувається повтор цих самих дій. Дана форма діалогу сприяє дисциплінованості оркестрового колективу. Прохання форма діалогу диригента з оркестрантами, яка передбачає виконання різних прохань диригента. Для прикладу, керівник може запропонувати виконати твір в характері, чи в повільному темпі, тощо. Бесіда - форма діалогу, в якій диригент спілкується з учасниками оркестрового колективу за допомогою запитань та відповідей. Як правило, бесіда відбувається про художній твір, який має бути виконаним. Вступна бесіда найчастіше готує оркестровий колектив до сприйняття нового музичного матеріалу.

Також можна зазначити, що комунікативна культура майбутнього диригента не може обмежуватися за допомогою даних видів комунікативного впливу. Окрім цього, даний процес потребує значних вольових зусиль та інтелектуального досвіду, оскільки тут задіяно значна кількість людей.

Психологічну взаємодію диригента 3 оркестрантами можна розділити на «зовнішню» та» внутрішню».

«Зовнішня» взаємодія спрямована більше на вирішення організаційних завдань. Вона характеризується здійсненням контролю та регулюванню дій усього оркестрового колективу.

«Внутрішня» - спосіб проникнення диригентом в духовний світ кожного оркестранта, пізнання їх «творчого внутрішнього світу».

3 цього приводу Г. Сржемський зазначає, що ці форми взаємодії мають власне співіснування, проте в подальшому розвитку істотно відміняються одне від одного. Якщо перший спосіб може бути віднесеним як і до «зовнішніх», так і до «внутрішніх» чинників, то процес «внутрішньої взаємодії спрямований на між особистий контакт диригента 3 самим собою, чи «уявно-граючим власним» оркестром.

В свою чергу Г. Макаренко (2006) зауважує, що комунікативний вплив у творчості диригента постає чинником моделі художнього образу, інструментом конкретизації професійних завдань та індивідуальним виразником психологічних відносин між диригентом та учасниками оркестрового колективу (с. 378). Тому саме слово керівника оркестру забезпечує максимально здоровий мікроклімат в оркестровому колективі, сприяє розкриттю творчого потенціалу кожного оркестранта та забезпечує найкращий результат колективного співіснування. Окрім цього комунікативна взаємодія диригента оркестрового колективу сприяє процесу створення нових художніх цінностей.

Висновки. На основі вище викладеного, можемо стверджувати, що комунікативна культура майбутнього диригента оркестру зароджується у процесі взаємодії з учасниками оркестрового колективу. Особливістю комунікативної культури майбутнього диригента оркестрового колективу є досягнення однієї думки з оркестрантами, стосовно художнього 
задуму композитора, стилістики твору, виконання штрихів, злагодженість у агогіці, побудові фраз, роботи по оркестровим групам.

Також слід відзначити, що комунікативна культура диригента взаємодіє із загальною культурою оркестрового колективу, стосовно сутності музичного твору, інтерпретації та виконання, адекватного ставлення та осмислення будь-якого музичного матеріалу. Тому комунікативна взаємодія диригента 3 оркестрантами спрямована на злагодженість у виконавстві, загальної емоційності та власній інтерпретації.

\section{ЛIТЕРАТУРА}

1. Бориснёв, С. В. (2003). Соииология коммуникаиии. Москва: ЮНИТИ-ДАНА.

2. Бусел, В. Т. (Ред.). (2005). Культура. Великий тлумачний словник сучасної украӥнської мови. Київ.

3. Верещагин, Е. М., \& Костомаров В. Г. (1990). Язык и культура. Москва.

4. Джузеппе, Р. (1979). Життя Ісуса Христа. Видання Українського католиџького університету ім. св. Климента Папи. (Т. XLIX-L, с. 180-186). Рим.

5. Ержемский, Г. Л. (1988). Психология дирижсирования: некоторые вопросы исполнительства и творческого взаимодействия дирижера с музыкальнылм коллективом. Москва: Музыка.

6. Живов, В. Л. (1998). Теория хорового исполнительства. Москва.

7. Зізіулас, Й. (2005). Буттяя як спілкування. Дослідження особистості і иеркви. Київ.

8. Карнеги, Д. (1991). Как завоевать друзей и оказывать влияние на людей. Владивосток.

9. Макаренко, Г. Г. (2006). Творчість диригента в контексті інтегративного підходу. (Дис. канд. д-ра наук). Національна музична академія України ім. П. І. Чайковського, Київ.

10. Малько, Н. А. (1965). Основы техники дирижирования. Москва: Музыка.

11. Маркевич, И. Высказывания. Исполнительское искусство зарубежных стран, 5. 21-23.

12. Мусин, И. (1967). Техника дирижирования. Ленинград: Музыка.

13. Попович, М. В. (2006). Культура в розмаїтості понять, явищ і схем поступу. Енщиклопедія історії Украӥни. (Т. 2, с. 60-61). Київ.

14. Слободяник, Н. В., \& Сверлюк Я. В. (2002). Основи знань керівників дитячих музично-аматорських колективів. Рівне.

15. Стоковський, Л. (1959). Музыка для всех нас. Москва, 1959. 